\title{
LETTERS
}

\section{Time to change pain paradigms}

Drs. Traeger and colleagues ${ }^{1}$ identify the continuing increase in societal costs resulting from low-back pain and associated disability. They provide one explanation: that patients are receiving low-value health services from their primary care physicians and that these physicians also underuse treatments known to improve low-back pain outcomes. The emphasis remains on detecting patients with serious physical injuries, despite that perhaps $1 \%$ of patients will harbour a serious injury and most pain-related disability is not predicted by injury severity. ${ }^{3}$ The implication is that many therapies and investigations cause worsened patient outcomes. This implication remains unproven; other explanations are possible.

The present back pain guidelines do not fit with the natural history of low-back pain in primary care: usually, $28 \%-60 \%$ of patients continue to have persistent pain and disability at one year; ${ }^{2,3}$ patients with back pain in primary care report high visual analogue scale levels, which reflect an extensive activation of a wide neuromatrix $^{4}$ with high risk for neuroplastic modification; and at least $30 \%$ or more of the variation in disability might be explained by patient distress and magnified illness behaviours at first assessment. ${ }^{5}$ Yetn intensive biopsychosocial treatments ${ }^{6}$ and back schools ${ }^{7}$ provide little disability prevention.

Our patients are in severe pain, with high risk for permanent disability and with a brain activation of a wide neuromatrix of mostly instinctual and emotional centres, and they rightly demand our help. Usually, recommending a hot pack won't cut it.

We may need to accept that the tissue injury model has failed and that a new paradigm is needed but is so far undeveloped. It will need to reflect the experience of primary care and the known natural history of the condition. ${ }^{8}$ One suggestion would be to measure the brain activations of actual patients in primary care instead of asymptomatic university students - and then adjust interventions to these activations. Perhaps it is time for a paradigm change.

\section{Fred E. Arthur BA MD}

Primary Care Physician, Western

University, London, Ont.

Cite as: CMAJ 2018 February 20;190:E200. doi: $10.1503 /$ cmaj.733579

\section{References}

1. Traeger A, Buchbinder R, Harris I, et al. Diagnosis and management of low-back pain in primary care. CMAJ 2017;189:E1386-95.

2. Henschke N, Maher CG, Refshauge KM, et al. Prognosis in patients with recent onset low back pain in Australian primary care: inception cohort study. BMJ 2008;337:a171.

3. Rundell SD, Sherman KJ, Heagerty PJ, et al. Predictors of persistent disability and back pain in older adults with a new episode of care for back pain. Pain Med 2017;18:1049-62.

4. Legrain V, Iannetti GD, Plaghki L, et al. The pain matrix reloaded: a salience detection system for the body. Prog Neurobio/ 2011;93:111-24.

5. Waddell G. Chronic low-back pain, psychologic distress, and illness behavior. Spine 1984;9:209-13.

6. Marin TJ, Van Eerd D, Irvin E, et al. Multidisciplinary biopsychosocial rehabilitation for subacute low back pain. Cochrane Database Syst Rev 2017;6:CD002193.

7. Poquet N, Lin CW, Heymans MW, et al. Back schools for acute and subacute non-specific low-back pain. Cochrane Database Syst Rev 2016;4:CD008325.

8. McWhinney IR, Freeman T. Textbook of family medicine. 3rd ed. New York: Oxford University Press; 2009.

Competing interests: None declared. 